\title{
AMYOTROPHIC LATERAL SCLEROSIS (ALS) IN GEORGE COSTELLA WOLFE'S YOU ARE NOT YOU (SOCIOLOGICAL APPROACH)
}

\author{
Haerani \\ English and Literature Department, Adab and Humanities Faculty, \\ Alauddin Islamic State University of Makassar, Indonesia \\ haeranim07@yahoo.com
}

\begin{abstract}
This thesis studied about Amyotrophic Lateral Sclerosis (ALS) based on the script of the movie You Are Not You which was released in 2014. This research aimed to describe and analyze the ways to heal and cure the ALS disease and how the main character's social life during facing this disease in the movie. This research focused on sociological approach and based on the theory of Amyotrophic Lateral Sclerosis (ALS) by National Institute of Health (NIH) theory. This research used descriptive qualitative method and used note taking as the instrument. The findings showed that there are twenty-three data from six ways to heal and to cure the disease, they are: two therapies from Physicians, four therapies from Pharmacists, one physical treatment, two occupational and speech therapies, two therapies from nutritionist and twelve therapies from social workers and home care and hospice nurse. Meanwhile, there are eight social interactions by Kate with other character (individual to individual) and there are six social interactions by Kate with more than one character (individual to group).
\end{abstract}

Key words: Amyotrophic Lateral Sclerosis (ALS), to heal, to cure and social life.

\begin{abstract}
Abstrak
Penelitian ini tentang penyakit Amyotrophic Lateral Sclerosis (ALS) berdasarkan skrip pada film You Are Not You yang ditayangkan pertama kali pada tahun 2012. Penelitian ini bertujuan untuk menjelaskan dan menganalisis cara mengobati penyakit ALS dan bagaimana kehidupan sosial si penderita penyakit dalam film tersebut. Penelitian ini menggunakan pendekatan sosiologi dan berdasarkan teori Amyotrophic Lateral Sclerosis (ALS) oleh National Institute of Health (NIH). Penelitian ini menggunakan metode deskriptif kualitatif dengan instrumen note taking. Penelitian ini menemukan dua puluh tiga data dari enam cara mengobati penyakit ALS yaitu melalui dua terapi dari dokter, empat terapi dari apoteker, satu terapi fisik, dua terapi peralatan dan terapi wicara, dua terapi diet dan dua belas terapi oleh perawat di rumah. Sementara, ada delapan interaksi individu dan enam interaksi kelompok yang dilakukan oleh Kate selama menghadapi penyakit ini.
\end{abstract}

Kata Kunci: Amyotrophic Lateral Sclerosis (ALS), merawat, mengobati dan kehidupan sosial.

\section{INTRODUCTION}

Movie is a reliable, mature technology capable of providing a compelling entertainment experience. Movie is considered to be an important art form, a source of popular entertainment and a powerful method for educating. Actually movie is a form of drama that used technology like camera. Nevertheless, the basic of movie and play is narrative text of literary work (Mckernan 2005: 9). 
Sociology of literature is research that concern about human problems. This research is interested by many researchers that assume literature as the mirror of life. Literature and society are like two sides of a coin; they cannot be separated. Through literature, we could see how the author depicts the society and their social circumstances. Literature is a representation of life. It reflects the life itself, or, in other words, it is life, which literature imitates or mirrors; and we can say that the subject matter of literature is the manifold experiences of human beings and society (Wellek and Warren 1949:89).

Literature was born for society, produced by society, and anything about society must be discussed (Bandel, 2006:4). Literature is a part of our life, it has important role in our society, culture, and society development. Moreover, (Kennedy, 1983:47) states that literature is kind of art that can offer pleasure and illumination. It gives us the beauty, fact, event, and imagination born from the process of contemplation or observation of social phenomena as living the impact of the reality and the restlessness of human being. In addition, literature presents life, which may happen in our social reality; as (Landy, 1972: 2) states, literature include all aspects of human activities in expressing any kinds of feelings, emotions, thoughts, and ideas. Literary work is very important because it presents life through its words.

Literary works are born as influenced by other literary works that has been there before (Pradopo, 1995: 223). As (Abrams, 1981: 36) defines that literary work as an imitation, or reflection or representation of the world and human life and the primary criterion applied to a work is that of the truth of its representation to the objects represents, or represent. Literature and medicine is an interdisciplinary research field that many researchers are interested. Since 1982, there was a magazine about literature and medicine which published by John Hopkins University, Baltimore.

Literature and medicine is kind of study which is not only discussed by literary critic, but also medicine experts and history of science's expert as well. For example, Thomas Mann's The Magic Mountain and The Death by Ivan by Tolstoy (Bandel, 2006:14). Briefly, literature has nothing to do with therapy or disease, and medicine rarely correlated each other. But, at least in Western tradition, both of them have a strong connection (Bandel, 2006:13).

"You're Not You" movie detail describes causes and how to heal the Amyotrophic lateral sclerosis. Amyotrophic lateral sclerosis is a (ALS), sometimes called Lou Gehrig's disease, is rapidly progressive, invariably fatal neurological disease that attacks the nerve cells (neurons) which responsible for controlling voluntary muscles (muscle action we are able to control, such as those in the arms, legs, and face). The disease belongs to a group of disorders known as motor neuron diseases, which are characterized by the gradual degeneration and death of motor neurons (National Institute of Neurological Disorders and Stroke: 2014).

The main interesting in this movie is disease experienced by main character, Kate who previously living in normal circumstance and then her life changed suddenly after she was diagnosed with Amyotrophic Lateral Sclerosis (ALS), one of 
the diseases whose way to heal has not found yet, even can stop or reverse the direction of natural flow of this disease. Kate as Hillary Swank in this movie shows us the struggle of a classical pianist with disease Amyotrophic lateral sclerosis (ALS). Kate gives us inspiration on how to appreciate our life. The movie gives us a message to appreciate our live and every life has its own story, happy ending or not it still is happy ending for someone.

"You're Not You" is based on the debut novel by writer Michelle Wildgen. It was released in the United Kingdom on 30 ${ }^{\text {th }}$ May 2006 by Thomas Dunn Books. Michelle Wildgen's novel "You Are Not You" is so skillfully rendered that it's hard to believe it is a first novel. The character of Bec who has a habit of falling into things jobs, love affairs is funny, completely unsentimental, and really great for a reader to hang around with. Her world view and how it changes when she goes to work for Kate, a refined woman in her thirties, is riveting. The movie "You're Not You" are started by Hilary Swank, Emmy Rossum, and Josh Duhamel (Internet Movie Database).

\section{THEORETICAL BACKGROUND}

\section{Sociological Approach}

Sociological terms in the first concept used by Augustus Comte. He called it a philosophical science. According to Comte in Doda (2005: 2) coined sociological terms is a combination of two words. The first part of terms is a Latin, socius- that may variously mean society, association, togetherness, or companionship. The other word, logos, is of Greek origin. It literally means to speak about or word. However, the terms are generally understood as study or science. Thus, the etymological, literal definition of sociology is that it is the word of speaking about society. A simple definition here is that it is the study of society and culture.

Eneste (1948: 67) states the problem, which appears on the literary works, is also the problem of the society. The problem that comes on the social and is passed by the society becomes important thing for the authors to build their creativity in producing literary works.

Sociological approach is one in studying literature which has reflective attitude. It then assumes that good work of literature is the works which can success reflect the era in which it is born (Fhatmawati, 2012:22). It shows the relations between sociology and literature, these two influence each other.

Certainly, the sociological approach it focuses on the problem of human beings. It is explained again by Goldman in Endraswara (2008: 78) there are some kinds of sociological approach, they are: 1. the researcher which sees the work of literature as social documentation which reflects the condition in which the works are created. 2. The research that sees the work of literature is the mirror of the social condition in which the writer writes the works. 3. The research that sees that the work of literature is manifestation of historical moments and social and cultural condition.

From the statement above, the researcher can conclude that sociology is the scientific study of human being interactions. It concludes some of human interaction 
in literary work for example film. A sociology of the film should have confronted is that of the relations between the film from itself and the structure of the social environment in which it developed.

\section{Amyotrophic Lateral Sclerosis (ALS)}

\section{a. Definition of Amyotrophic Lateral Sclerosis}

Amyotrophic Lateral Sclerosis (ALS), is a progressive neurodegenerative disease that affects nerve cells in the brain and the spinal cord. A-myo-trophic comes from the Greek language. "A" means no, "Myo" refers to muscle, and "Trophic" means nourishment - "No muscle nourishment". When a muscle has no nourishment, it "atrophies" or wastes away. "Lateral" identifies the areas in a person's spinal cord where portions of the nerve cells that signal and control the muscles are located. As this area degenerates it leads to scarring or hardening ("sclerosis") in the region.

Amyotrophic lateral sclerosis (ALS), sometimes called Lou Gehrig's disease, is a rapidly progressive, invariably fatal neurological disease that attacks the nerve cells (neurons) responsible for controlling voluntary muscles (muscle action we are able to control, such as those in the arms, legs, and face). The disease belongs to a group of disorders known as motor neuron diseases, which are characterized by the gradual degeneration and death of motor neurons. Motor neurons are nerve cells located in the brain, brain stem, and spinal cord that serve as controlling units and vital communication links between the nervous system and the voluntary muscles of the body. Messages from motor neurons in the brain (called upper motor neurons) are transmitted to motor neurons in the spinal cord (called lower motor neurons) and from them to particular muscles. In ALS, both the upper motor neurons and the lower motor neurons degenerate or die, and stop sending messages to muscles. Unable to function, the muscles gradually weaken, waste away (atrophy), and have very fine twitches (called fasciculations).

Eventually, the ability of the brain to start and control voluntary movement is lost. 1/2 ALS causes weakness with a wide range of. Eventually, all muscles under voluntary control are affected, and individuals lose their strength and the ability to move their arms, legs, and body. When muscles in the diaphragm and chest wall fail, people lose the ability to breathe without ventilatory support. Most people with ALS die from respiratory failure, usually within 3 to 5 years from the onset of symptoms. However, about 10 percent of those with ALS survive for 10 or more years. Although the disease usually does not impair a person's mind or intelligence, several recent studies suggest that some persons with ALS may have depression or alterations in cognitive functions involving decisionmaking and memory. ALS does not affect a person's ability to see, smell, taste, hear, or recognize touch. Patients usually maintain control of eye muscles and bladder and bowel functions, although in the late stages of the disease most individuals will need help getting to and from the bathroom (NINDS: 2010). 


\section{b. The Causes of Amyotrophic Lateral Sclerosis (ALS)}

The causes of Amyotrophic lateral sclerosis (ALS) are not known, and scientists do not yet know why ALS strikes some people and not others. An important step toward answering this question was made in 1993 when scientists supported by the National Institute of Neurological Disorders and Stroke (NINDS) discovered that mutations in the gene that produces the SOD1 enzyme were associated with some cases of familial ALS. Although it is still not clear how mutations in the SOD1 gene lead to motor neuron degeneration, there is increasing evidence that mutant SOD1 protein can become toxic.

Since then, over a dozen additional genetic mutations have been identified, many through NINDS-supported research, and each of these gene discoveries has provided new insights into possible mechanisms of ALS. For example, the discovery of certain genetic mutations involved in ALS suggests that changes in the processing of RNA molecules (involved with functions including gene regulation and activity) may lead to ALS-related motor neuron degeneration. Other gene mutations implicate defects in protein recycling. And still others point to possible defects in the structure and shape of motor neurons, as well as increased susceptibility to environmental toxins. Overall, it is becoming increasingly clear that a number of cellular defects can lead to motor neuron degeneration in ALS.

Another research advance was made in 2011 when scientists found that a defect in the C9orf72 gene is not only present in a significant subset of ALS patients but also in some patients who suffer from a type of front temporal dementia (FTD). This observation provides evidence for genetic ties between these two neurodegenerative disorders. In fact, some researchers are proposing that ALS and some forms of FTD are related disorders with genetic, clinical, and pathological overlap.

In searching for the cause of ALS, researchers are also studying the role of environmental factors such as exposure to toxic or infectious agents, as well as physical trauma or behavioural and occupational factors.

\section{c. Treatment to heal and cure Amyotrophic Lateral Sclerosis}

No cure has yet been found for ALS. However, the Food and Drug Administration (FDA) approved the first drug treatment for the disease riluzole (Rilutek: 1995). Riluzole is believed to reduce damage to motor neurons by decreasing the release of glutamate. Clinical trials with ALS patients showed that riluzole prolongs survival by several months, mainly in those with difficulty swallowing. The drug also extends the time before an individual needs ventilation support. Riluzole does not reverse the damage already done to motor neurons, and persons taking the drug must be monitored for liver damage and other possible side effects. However, this first disease-specific therapy offers hope that the progression of ALS may one day be slowed by new medications or combinations of drugs. 
Other treatments for ALS are designed to relieve symptoms and improve the quality of life for individuals with the disorder. This supportive care is best provided by multidisciplinary teams of health care professionals such as:

a. Physicians; Physicians can prescribe medications to help reduce fatigue, ease muscle cramps, control spasticity, and reduce excess saliva and phlegm. Drugs also are available to help patients with pain, depression, sleep disturbances, and constipation.

b. Pharmacists; Pharmacists can give advice on the proper use of medications and monitor a patient's prescriptions to avoid risks of drug interactions.

c. Physical; Physical therapy and special equipment can enhance an individual's independence and safety throughout the course of ALS. Gentle, low-impact aerobic exercise such as walking, swimming, and stationary bicycling can strengthen unaffected muscles, improve cardiovascular health, and help patients fight fatigue and depression. Range of motion and stretching exercises can help prevent painful spasticity and shortening (contracture) of muscles. Physical therapists can recommend exercises that provide these benefits without overworking muscles.

d. Occupational, and speech therapists; Occupational therapists can suggest devices such as ramps, braces, walkers, and wheelchairs that help individuals conserve energy and remain mobile. People with ALS who have difficulty speaking may benefit from working with a speech therapist. These health professionals can teach individuals adaptive strategies such as techniques to help them speak louder and more clearly. As ALS progresses, speech therapists can help people develop ways for responding to yes-or-no questions with their eyes or by other nonverbal means and can recommend aids such as speech synthesizers and computer-based communication systems. 1112 These methods and devices help people communicate when they can no longer speak or produce vocal sounds.

e. Nutritionists; Nutritional support is an important part of the care of people with ALS. Individuals and caregivers can learn from speech therapists and nutritionists how to plan and prepare numerous small meals throughout the day that provide enough calories, fiber, and fluid and how to avoid foods that are difficult to swallow. People may begin using suction devices to remove excess fluids or saliva and prevent choking. When individuals can no longer get enough nourishment from eating, doctors may advise inserting a feeding tube into the stomach. The use of a feeding tube also reduces the risk of choking and pneumonia that can result from inhaling liquids into the lungs.

f. Social workers and home care and hospice nurse; Social workers and home care and hospice nurses help patients, families, and caregivers with the medical, emotional, and financial challenges of coping with ALS, particularly during the final stages of the disease. Respiratory therapists can help caregivers with tasks such as operating and maintaining respirators, and home 
care nurses are available not only to provide medical care but also to teach caregivers about giving tube feedings and moving patients to avoid painful skin problems and contractures. Home hospice nurses work in consultation with physicians to ensure proper medication and pain control.

\section{METHODOLOGY}

The writers used descriptive qualitative method with sociological approach based on National Institute of Health (NIH) Theory. The data were divided into two types, namely primary data and secondary data. The primary data was taken from the movie You Are Not You by George Costella Wolf released in 2014 with one hour and fortytwo minutes long. The secondary data were collected from books, websites, PDF printed-journal, internet free encyclopedia and other sources that relevant and related to the topic of this research. In conducting the research, the writer used note taking as the research instrument. Ray (2005:13), defines note taking is a method in assembling data required by using note cards to write down the data findings from source data.

\section{DISCUSSION}

In the discussion section, the researchers explained the data analysis that had been found in You Are Not You movie. The researchers watched the movie and indentified the ways to heal and cure the ALS disease and how the main character's social life during facing this disease based on NIH theory. This theory divided into six ways to heal and to cure the disease they are: Physicians, Pharmacists, physicals, Occupational and speech therapists, nutritionist and Social workers and home care and hospice nurse. Meanwhile, there are eight social interactions by Kate with other character (individual to individual) and there are six social interactions by Kate with more than one character (individual to group).

\section{How to heal and cure the disease}

The way to heal and cure were indentified and analyzed based on the National Institute of Health $(\mathrm{NIH})$ theory about the disease of Amyotrophic Lateral Sclerosis (ALS). The research findings would explain how to heal and cure the disease in the George Costella Wolfe's "You're Not You" movie.

a. Physicians can prescribe medications to help the patient of Amyotrophic Lateral Sclerosis (ALS) to reduce fatigue, ease muscle cramps, control spasticity, and reduce excess saliva and phlegm.

Datum 1 (Kate consultation with her Physician: a Doctor 00:44;11-00:44;25)

Kate : I'm now in the chair, and it's harder to breathe. My voice to -- especially at night.

Doctor : Well, that's to be expected. This process only moves in one direction, but attitude goes a long way, Kate.

Datum 2 (Kate makes a consultation again for the next treatment 00:56;59-00:57;25) 
Doctor : six months ago, you are breathing at a 64 percent capacity. Now it's 43. Are you wearing your BiPAP at night?

Kate : No. I don't like it. It makes me feel like I'm suffocating.

Doctor : Well, look, Kate, it's gonna get harder and harder for you to get oxygen into your lungs. Soon, we'll be looking at a permanent ventilator.

Bec : But when she's on the machine, can she even talk?

b. Pharmacists can give advice on the proper use of medications and monitor a patient's prescriptions to avoid risks of drug interactions.

Datum 3 (The doctor suggest Kate to wear her BiPAP 00:57;04-00:57;15)

Doctor : six months ago, you are breathing at a 64 percent capacity. Now it's 43 . Are you wearing your BiPAP at night?

Kate $\quad$ : No. I don't like it. It makes me feel like I'm suffocating.

Datum 4 (Kate hard to breathe and doctor suggest to using permanent ventilator for the next treatment 00:57;16-00:57;25)

Doctor : Well, look, Kate, it's gonna get harder and harder for you to get oxygen into your lungs. Soon, we'll be looking at a permanent ventilator.

$\mathrm{Bec}$ : But when she's on the machine, can she even talk?

Datum 5 (Evan explain to Bec for give more vitamins and immune-boosts 00:11;50$00: 12 ; 00)$

Kate $\quad$ : evan, I can show her.

Evan $\quad:$ hold on. You add your vitamins... and your immune-boosts. Alright? We wanna keep as many calories in her as we can. Low fat is the enemy...

Datum 6 (Gwen as Kate's mother want to give her permanent ventilator 01:24;14$01: 24 ; 20)$

Doctor : No, it's not settled. It's not what Kate wants. Legally, yes you're right.

Gwen : No, she goes on ventilator now.

c. Physical therapy can enhance an individual's independence and safety throughout the course of Amyotrophic Lateral Sclerosis (ALS). Physical therapists can recommend exercises that provide these benefits without overworking muscles.

Datum 7 (Bec give some exercise treatment to Kate in swimming pool 00:45;34$00: 45 ; 43)$

\footnotetext{
$\mathrm{Bec}$

own a mile away. I'm right, aren't I?

Kate : Yes.
}

d. Occupational therapists can suggest devices such as ramps, braces, walkers, and wheelchairs that help individuals conserve energy and remain mobile. 
Datum 8 (Bec explain to Kate how to try use a wheelchair 00:45;00-00:45;22)
$\mathrm{Bec}$
: Oh my God. I look like you. Girl, go!
This is, like, the Porsche wheelchairs and it's just sitting here.
Kate
: I know. Evan bought it for me a year ago.
$\mathrm{Bec}$
: So what's the problem?
Kate
: Riding in one of those is like admitting I'm sick. Which I am, so it's crazy.

Datum 9 (Kate wearing her wheelchair in the market 00:45;25-00:45;33)

$\mathrm{Bec}$

: Go girl. I'm catching up. Go on. Ooh!

e. Nutritionists; Nutritional support is an important part of the care of people with Amyotrophic Lateral Sclerosis (ALS) and caregivers can learn from nutritionists how to plan and prepare numerous small meals throughout the day that provide enough calories, fiber, and fluid and how to avoid foods that are difficult to swallow.

Datum 10 (Evan explain to Bec for give many calories for Kate's health 00:11;40$00: 12 ; 00)$
Evan
Kate
Evan
Kate : I can show her.
: Mm. You got your broccoli. You got your beets.
: Evan, you'll be late.
: Carrots. Got your chopping board. You got your knife. After you chop...
Evan
: Hold on. You add your vitamins... and your immune-boosts. Alright? We wanna keep as many calories in her as we can. Low fat is enemy...

Datum 11 (Kate tries to explain how to makes a healthy drink to Bec in the first time 00:12;36-00:00:12;44)

$\begin{array}{ll}\text { Kate } & \text { : You don't put the broccoli stems in the blender. Just the flower heads. } \\ \text { Bec } & \text { : Don't worry. I'm not trying to calculate when I'm gonna need to get } \\ \text { another gig. }\end{array}$

f. Social workers and home care and hospice nurse; Social workers and home care and hospice nurses help patients, families, and caregivers with the medical, emotional, and financial challenges of coping with Amyotrophic Lateral Sclerosis (ALS), particularly during the final stages of the disease.

Datum 12 (Evan and Kate discuss about new nurse to Kate 00:08;32-00:09;00)

Evan : Did Mrs.Trotter say, she was gonna be late?

Kate : She's not coming.

Evan : What do you mean? As in all day she's not coming?

Kate : As in I let her go.

Evan : Wait. Wait, wait, wait. What?

Kate : She made me feel like a patient. I'm not a patient.

Evan : Kate. Kate. Katie, listen. We finally found somebody who was efficient. Somebody who I can trust. Somebody who can be flexible when I'm running late. You can't just be making these decisions without...

Datum 13 (Kate makes a interview job for new caregiver, 00:09:01-00:09;26) 


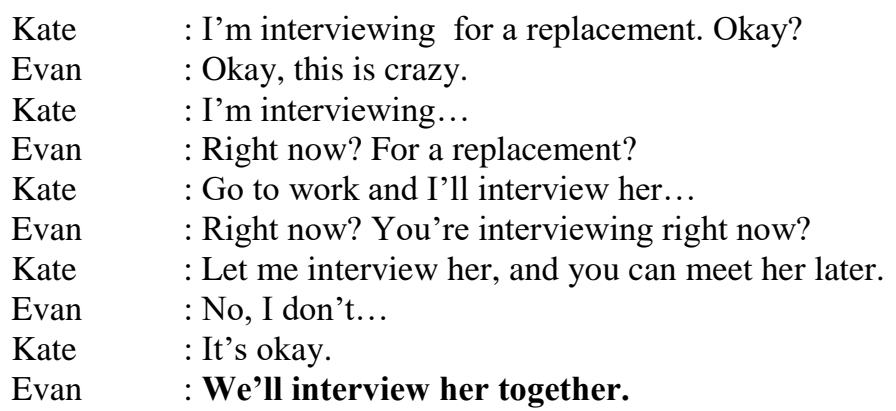

Datum 14 (Evan give some question to caregiver candidate, 00:10;55-00:11;06)

Evan : I assume housekeeping isn't your skill set. Do you cook? Any nursing experience? Tell me, Bec, have you ever seen, let alone cared for, someone suffering from a major degenerative illness?

Datum 15 (Bec tells about her nursing experience, 00:11;23-00:11;36)

Bec : Back in high school, I volunteered at a nursing home in Tyler. $\mathrm{Mm}-$ $\mathrm{hm}$. They stuck my Grammy Jones in there and I was there a lot. I didn't put it down "cause it was a while ago.

Datum 16 (Bec accompanied Kate to shopping in the market, 00:23;09-00:23;22)

$\mathrm{Bec}$

: So before we buy out the rest of Texas, you should probably know I can't cook anything. Like, not even Pop-Tarts.

Kate $\quad$ : That's fine.

Bec : I mean, like, at all.

Kate $\quad$ : You don't need to know how to cook. You just need to know how to listen.

Datum 17 (Bec help Kate to breathe well 00:41;22-00:41;37)

Bec : Hey, okay. Uh, shit, shit, shit. Okay. Okay, um... Drink. Drink. Hey! Okay, just breathe. Breathe. Just breathe. Breathe with me. Breathe. Hey. What do I do? Shit. Shit.

Operators : You contacted Emergency Alert. Help is on the way.

Datum 18 (Kate ask to Bec for cancel the emergency call, 00:41;40-00:42;00)

Kate : Cancel.

Bec : What? You want me to cancel? This is, uh, Bec Cartwell, calling on behalf of Katherine Parker. I accidentally triggered the alarm and I need to cancel it. Thank you.

Datum 19 (Bec as Kate home caregiver, 00:43-37)

Bec : Do you ever listen to anything I say? Kate, the patient friend I take care of. Something funny?

Liam : You're actually responsible for another person's life? Where you going?

This scene above shows that Bec tells Liam she is caring for someone named Kate. Being a nurse, actually like home care.

Datum 20 (Bec tries to help Kate when she hard to breathe well, 00:53;27-00:53;33) Bec : Okay, okay, okay. I got her, I got her. Just breathe. Take it slow.

Datum 21 (Kate's father read the Kate's attorney, 01:23;45-01:24;00) 


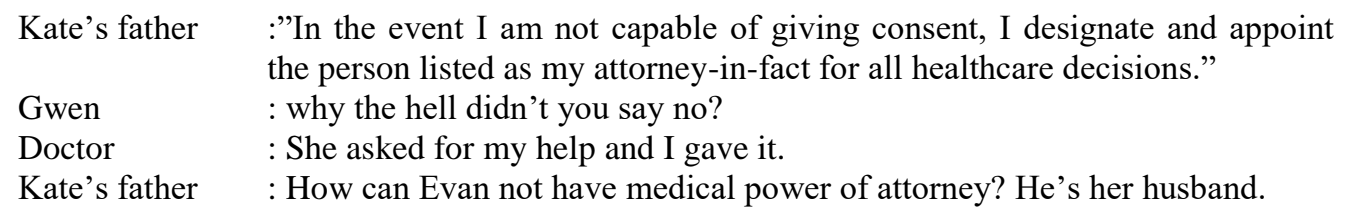

Datum 22 (Evan explain to Bec as Kate's caregiver, 01:24;49-01:25;01)

Bec : When did she come in?

Evan : Earlier tonight.

Bec : Did they ventilate her? She didn't want that.

Evan : Not yet. They wanna talk to you first. Alright. She left it up to you.

Datum 23 (Bec makes a decision and she talk with the doctor about Kate want to go to home, 01:26;13-01:26;53)

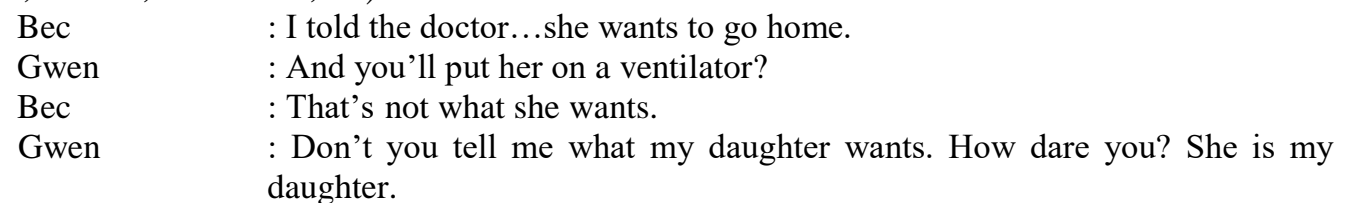

\section{EXPLANATION}

\section{How to heal and cure the disease}

a. Physicians can prescribe medications to help the patient of Amyotrophic Lateral Sclerosis (ALS) to reduce fatigue, ease muscle cramps, control spasticity, and reduce excess saliva and phlegm.

Based on Datum 1, Kate explained her condition with chair now and she was hard to breathe, and a doctor tried to give an answer to Kate about her condition and what Kate would do in the future for her health and what happened after that.

Datum 2, Doctor asked to his patient, were Kate wearing her BiPAP at night? And Kate answered it, no, she did not like it because it made her suffocating if she wears it. Then a doctor gave a suggestion to wear permanent ventilator for Kate to breathe well soon. This thing was one of the treatments for ALS patient, made consultation with a doctor to know her condition, what she would do, and what the next treatment was for her health.

Based on the datum above the researcher can conclude that Datum 1 and 2 indicated Physicians where patient had a consultation with someone who knew her condition very well, this was one of the steps in treatment for ALS patient so that she could decide what she should do next. And also physicians it could prescribe medications to reduce fatigue, ease muscle cramps, control spasticity, and reduce excess saliva and phlegm. Drugs were also available to help patients with pin, depression, sleep disturbances, and constipation.

b. Pharmacists can give advice on the proper use of medications and monitor a patient's prescriptions to avoid risks of drug interactions.

There are four scenes that show pharmacists treatment they are Datum 3, this scene above indicated Pharmacists because a doctor asked for Kate to wear her 
BiPAP to get a better air, because she could not get the air as much as she needed. Biphasic Positive Airway Pressure (BiPAP) could be described as pressure controlled ventilation in a system allowing unrestricted spontaneous breathing at any moment of the ventilator cycle.

Datum 4, Ventilator was one of the tools for patients who had difficulty in breathing. And this was something that must be done by the Amyotrophic Lateral Sclerosis (ALS) patient to breathe easily. They eventually lose the ability to breathe on their own and must depend on ventilator support for survival.

Datum 5, this scene above indicated pharmacists because Evan as her husband gave her some vitamins for consumption, to remain her immune system stable. Some immune-boosts should be consumed by Amyotrophic Lateral Sclerosis (ALS) patients because it could improve the quality life of patients.

Datum 6, this scene above also indicated pharmacist because Kate's mother wanted her daughter to get advanced treatment which was put on ventilator permanently so that could survive much longer.

Based on the datum above the researcher conclude that Datum 3,4 5 and 6 indicated pharmacists because patient with Amyotrophic Lateral Sclerosis (ALS) requires some specific vitamins for better life. As explained by Evan to Bec as the new candidate to take care of Kate later. Kate must have enough foods and vitamins for her immune. Kate was also suggested to keep applying BiPAP to breathe easily. And if her lung was hard to breathe las usual, then doctor highly recommended to wear ventilator permanently to keep her alive. Pharmacists could give advice on the proper use of medications and monitor a patient's prescriptions to avoid risks of drug interactions.

c. Physical therapy can enhance an individual's independence and safety throughout the course of Amyotrophic Lateral Sclerosis (ALS). Physical therapists can recommend exercises that provide these benefits without overworking muscles.

This scene in Datum 7, Kate and Bec were in a pool, Bec helped Kate to do Exercise such as swimming. Swimming was one treatment for patients with Amyotrophic Lateral Sclerosis (ALS) while the patients could improve cardiovascular health, and helped patients fight fatigue and depression.

Based on Datum 7 the researcher can conclude, this scene above indicated physical therapy because swimming was the way to train ALS patient's nerves and muscle keep moving flexibly. As Kate does, Bec tried to help her to move her foot. Gentle, low-impact aerobic exercise such as walking, swimming, and stationary bicycling could strengthen unaffected muscles, improve cardiovascular health, and help patients fought fatigue and depression. Range of motion and stretching exercises could help to prevent painful spasticity and shortening (contracture) of muscles.

d. Occupational therapists can suggest devices such as ramps, braces, walkers, and wheelchairs that help individuals conserve energy and remain mobile. 
Based on Datum 8, this scene above indicated in occupational therapy because wheelchairs that helped individuals to converse energy and to remain mobile. In certain circumstances the patients of Amyotrophic Lateral Sclerosis (ALS) needed a wheelchair to enable them to move and traveled far enough.

In the same way Datum 9 is also shows that in this scene Kate tried to use a wheelchair when shopping in supermarkets. This was one of the therapists that patients of Amyotrophic Lateral Sclerosis (ALS) that used a wheelchair to facilitate Kate to perform daily activities, such as going shopping.

Based on the datum above the researcher conclude that Datum 8 and 9, these indicated occupational therapy, where in the therapy, Kate tried to keep moving and made sure her nerves and tendons could be moved even though it had been a bit rigid. As the define of occupational therapists could suggest devices such as ramps, braces, walkers, and wheelchairs that help individuals conserve energy and remain mobile.

e. Nutritionists; Nutritional support is an important part of the care of people with Amyotrophic Lateral Sclerosis (ALS) and caregivers can learn from nutritionists how to plan and prepare numerous small meals throughout the day that provide enough calories, fiber, and fluid and how to avoid foods that are difficult to swallow.

Based on Datum 10, she should be consuming a lot of calories. Maintaining weight would then become a problem. Therefore, Evan told Bec that make low-fat food as in their brief conversation.

In the same way Datum 11, the scene above showed us that Bec was smoothing broccoli and other vegetables for Kate consumption because she was difficult swallowing and chewing. Kate must consume specific food in order to make her easily digests it well.

Based on the datum above the researcher conclude that Datum 10 and 11, these indicated nutritional support was an important part of the care of people with Amyotrophic Lateral Sclerosis (ALS). With helps from nutritionists Evan and Kate were able to decide easily how to plan and prepare numerous small meals throughout the day that provide enough calories, fiber, and fluid and how to avoid foods that were difficult to swallow. As explained by Evan conversation in Datum 10 and in scene of Datum 11.

f. Social workers and home care and hospice nurse; Social workers and home care and hospice nurses help patients, families, and caregivers with the medical, emotional, and financial challenges of coping with Amyotrophic Lateral Sclerosis (ALS), particularly during the final stages of the disease.

There are twelve scenes that show patient Amyotrophic Lateral Sclerosis (ALS) needed Social workers and home care and hospice nurse to help the patient. In Datum 12, Kate needs someone to keep her when Evan was working, or accompanied her when Evan came home late. As well as taking care of everything that she wanted when Evan as her husband was not in around her. 
Datum 13, this scene shows that Kate want to replace nurses, that want to take care of her and would do job interviews with prospective caregivers. And Evan wanted to do the interview with Kate because he was not sure with the prospective nurses would take care of his wife.

Datum 14, this scene above shows that Evan was doing job interviews with prospective nurses who would care his wife. Evan asked Bec, whether Bec had any experience caring for people with degenerative illness, this was done to determine whether the caregivers understood the patient's condition.

Datum 15, this scene above shows that Bec had been a volunteer, and she had any experience of caring for someone in senior high school.

Datum 16, this scene shows Bec was accompanying Kate for shopping in the market for the event which would be Kate briefly the night with her friends. This was one Bec job's as a home nurse.

Datum 17, this scene above indicated respiratory therapist could help caregiver with task such as operating and maintaining respirators, and home care nurses were available not only to provide medical care but also to teach caregivers about giving tube feedings and moving patients to avoid painful skin problem and contractures.

Datum 18, this scene above shows Bec tried to contact the hospital where she was treated by push the alert which was already there. Home hospice nurse work in consultation with physicians to ensure proper medication and pain control. It was one of Bec duties as an appointed health care's to look after her. When an undesirable thing happened, Bec was right to call emergency unit for the safety of patients.

Datum 19, this scene above shows that Bec tells Liam she was caring for someone named Kate. Being a nurse, actually like home care.

Datum 20, this scene above indicated Kate was having difficulty breathing and coughing and Bec had a duty as a nurse help to conduct Respiratory therapist for she felt better to breathe.

Datum 21, this scene above shows Kate father's read out a will that she made, who was entitled to appoint an attorney for her health. And if her condition became worse, an attorney for her health had a right to determine what should be taken for her health.

Datum 22, this scene above indicated Evan as her husband tells Bec that she refers to himself as a nurse at once an attorney of her health. And all things related to her health were now in Bec decision.

Datum 23, this scene depicts Kate Bec as an attorney health was entitled to decide what the patient wants. And Bec chose not to give Kate a permanent ventilator because she felt that she did not have to die with his body machines.

Based on the datum above the researcher concluded that Datum 12, 13, 14, 15, 16, 17, 18, 19, 20, 21, 22, and 23 these scenes indicated Social workers and home care and hospice nurses helped patients, families, and caregivers with the medical, emotional, and financial challenges of coping with Amyotrophic Lateral Sclerosis (ALS), particularly during the final stages of the disease. Home hospice nurses worked in consultation with physicians to ensure proper medication and pain control. 
Bec as nurse including consultant of health for Kate to made sure if something happened to Kate, then Bec deserved to decide what she should do next. Not only as private nurse, Bec also assumed as someone whom Kate cared about and also as family for Kate. Kate also trusted for her health issue in Bec.

The researchers make conclusions that treatments of patient Amyotrophic Lateral Sclerosis (ALS) mostly used for social workers and home care and hospice nurse by Bec as second main character in "You're Not You" movie. It means that Bec was often helping other people as Kate caregivers. It refers to characteristic of Bec that who cared about other people because she really likes her as her sister.

The result of this research above also support the previous findings of Anwar (2011) who used movie as her object research and Nurwahidah (2016) who used diseases as her object research. They also found the heal and cure the diseases that similar with this research.

\section{CONCLUSION}

The conclusion from the analysis above there are twenty-three therapies and treatments from six ways to heal and cure the Amyotrophic Lateral Sclerosis (ALS) diseases in the "You're Not You" movie, namely the physicians 2 therapies, pharmacists 4 therapies, a physical treatment, occupational 2 therapies, nutritionist 2 treatments, and social workers and home care and hospice nurse 12 treatments. Besides, there are eight social interactions by Kate with other character (individual to individual) and there are six social interactions by Kate with more than one character (individual to group).

\section{REFERENCES}

Abrams, M. H. 1981. A Glossary of Literary Form. Third Edition. New York: Holt Rinerhart and Winston Inc.

Anwar, Rita Kusumadewi. 2011. Coping with The Child of Acute Promyelocytic Leukemia in Nick Cassavates' My Sister Keeper (2009): An Individual Psycological Perspective. Yogyakarta: Muhammadiyah University of Surakarta.

Bandel, Katrin. 2006. Sastra, Perempuan, Seks. Yogyakarta: Jalasutra.

Cristiani, Marco, et al. 2011. Social Interaction Discovery by Statistical Analysis of Formations, [Online Article], No.2. Retrieved from www.lorisbazzani.info/...Cristanietal_BMVCII. Acessed on February 13, 2016.

Doda, Zehirun. 2005. Introduction to Sociology. Debub University: United States.

Endraswara, Suwardi. 2011. Methodologi Penelitian Sastra: Epistemologi, Model, Teori, dan Aplikasi. Yogyakarta: CAPS.

Eneste, Pamusuk. 1984. Social Problem. Wellington: Department of conservation.

John Hopkins University. 2015. Medicine and Literature. Baltimore, Amerika Serikat: The Institute for Medical Humanities at UTMB Galveston. (www.johnhopkins/univ) (Accessed on October 2015).

Kennedy, William. 1983. How to Analyze Frosh. New York: Monarch Press. 
Landy, Joseph. 1972. Insight a Study of Short Story. Manila: Jesuit education association.

Macionis, John J. 2007. Sociology. United states of America: Pearson Prentice Hall.

Mckernan, Brian. 2005. Digital Cinema: The Revolution in Cinematography, Postproduction and Distribution. New York.: Mcgraw-Hill.

National Institute of Neurological Disorder and Stroke (NINDS). 2010. Amyotrophiclateral Sclerosis: U.S. Departement of Health and Human Service: Public Health Service National Institutes of Health.

SR, Nurwahidah. 2016. Memory Loss Anterograde Amnesia in SJ Watson Movie "Before I Go to Sleep". Makassar. State Islamic University of Alauddin Makassar.

Tom Burn, Elizabeth. 1973. Sociology Literature and Drama. Australia. Penguin Books.

Pradopo, Rahmat Djoko. 1995. Beberapa Teori Sastra, Metode Kritik, dan Penerapannya. Yogyakarta: Universitas Negeri Yogyakarta.

Ray. 2005. Note Taking Startegies. Peen: Peen States University.

Scheinkman, Jose A. 2007. Social Interaction. Columbia University Press: New York.

Soekanto, Soerjono. 2013. Sosiologi: Suatu Pengantar. Jakarta: Raja Grafindo Persada.

Wellek, Warren. 1949. Theory of Literature. Thirty Oxford Square: London. 